\title{
韓国慶州における旧鉄道官舎地区の居住空間の変容に関する考察 A CONSIDERATION ON THE TRANSFORMATION OF LIVING SPACE OF RAILROAD TIED RESIDENCE DISTRICT IN THE KYONGJU, KOREA
}

\author{
趙 聖 民*，布野修司 ${ }^{* *}$ \\ Sungmin CHO and Shuï FUNO
}

\begin{abstract}
This paper aims to clarify spatial transformation of Japanese railroad tied residence district in the Kyongju city (KOREA). Kyongju railroad tied residence area had built 37 semi-detached houses as railroad tied residences. Japanese style railroad tied residence was introduced and modified by Korean occupants. In this paper, we discuss spatial pattern of Kyongju railroad tied residence and the transformation process of living space.

Kyongju railroad tied residence area still maintain the original formation and appearance although over 70 years have passed since its foundation. However, transformation has began since railroad tied residence was handed to the new inhabitants in 1970. As for exterior space, we found out 'TEOTBAT' and 'GOSAT', which are both semi private and semi public space for inhabitants in this district. It is also pointed out that 'Living room' and MADANG are created in the Railroad Tied Residences. The appearance of 'MADANG' and 'Living room' are caused by position change of entrance. In particular, transformations are seen at the position of toilet, kitchen and living room.
\end{abstract}

Keywords : Kyongju, Colonial City, Railroad Town, Railroad Tied Residence, Living Space, Transformation 慶州、植民都市、鉄道町、鉄道官舎、居住空間、変容

1. はじめに

\section{$1-1$ 研究の目的と意竞}

本稿は、「日本植民地期における日本人によって形成された鉄道町 の形成とその変容に関する研究」 ${ }^{1)}$ の一環として、慶尚北道慶州市の 旧鉄道官舎地区を対象として、居住空間の構成とその変容について 考察することを目的としている。鉄道町は、開港場 ${ }^{2)}$ と共に韓半島 の近代都市の起源であり、今日に至る都市構造に大きな影響を与え てきている。前稿 ${ }^{3)}$ では、慶尚南道密陽市三浪津邑の鉄道町におけ る都市形成と土地所有者変化を土地台帳をもとに明らかにし、三浪 津邑松旨里の都市化、鉄道町の形成過程、そして土地利用の変化、 および鉄道官舎、駅前商店街の日式住宅の変容に関する考察を行っ t。

本稿では、同様な方法によって歴史都市慶州の旧鉄道官舎地区の 形成過程と居住空間の変容を明らかにする。慶州は韓国の代表的な 古都であり、様々な文化遺産が残っている世界文化遺産に登録され た観光都市でもある。また、定型的な鉄道官舎の変容パターンを解 明することによって、韓日の居住文化を比較する上で有力な手掛か りを得るのが目的である。

慶州に関する研究や文献は非常に多いが、そのほとんどが歴史、 考古学、文化遺産などの分野に偏っており、近代期の慶州に関する 文献は非常に少ない。特に、日本の植民地期に建設された鉄道町に 関する研究はほとんどない。そうした中で『朝鮮鉄道線路案内』4) と『朝鮮と建築』 ${ }^{5)}$ は本稿にとって重要な手がかりとなる。また、日 本植民地期における日式住宅、及び鉄道町に関する既往の研究には、
이현희 Lee Hyeun-Hea の「韓国における日式住宅の変遷とその影響に 関する研究 $j^{6)}$ 、채기병 Chae Gi-Byung, 김태영 Kim Tai-Young の「鉄 道建設における近代的都市構造の形成に関する研究」?)、주우일 Ju U-IL、김상호 Kim Sang-Ho、이상정 Lee Sang-Jung の「近代化の過程 で建立された晋州鉄道官舎の平面類型に関する研究 $\rfloor^{8)}$ 、김수영 Kim Su-Young、박용환 Park Young-Hwan の「解放以前における鉄道官舎の 平面特性に関する研究」 なな゙がある。以上の研究は、鉄道町におけ る街区形態の分類、官舎の類型、変容が行われる以前の鉄道官舎に 主な焦点を当てている。日本植民地期の都市計画に関する主要な文 献は末尾に示す通りである。

本稿では、実測調查とヒ ヤリングを基に、韓国人の 居住者によって現れた新た な空間と機能を明らかにす ることを視点とし、変容の 要因を中心に考察している。 本稿の対象である慶州及 び慶州鉄道官舎地区の特徵 を簡単にまとめると以下の ようになる。

新羅時代の約一千年にわた る首都 ${ }^{10)}$ で数多くの文化遗跡 が残されている。植民地期 に朝鮮総督府によって文化

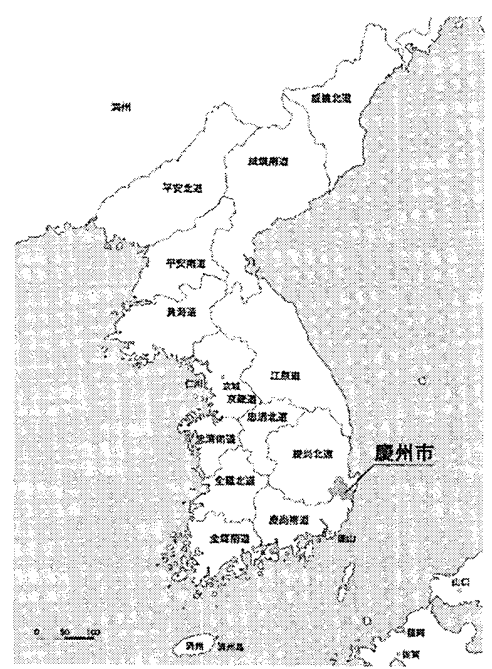

图 1 韓半岛と慶州
* 滋賀県立大学大学院環境科学研究科 博士後期課程 - 修士

** 滋賀県立大学大学院環境科学研究科教授.工博
Graduate Student, University of Shiga Prefecture, M. Env. Prof., University of Shiga Prefecture, Dr. Eng. 
遺跡の発掘、復元、修復などの事業が行われ、以降「歴史文化都市」 として発展してきている。

国鉄京釜線の分線にある慶州駅は、釜山、大邱、浦港、安東、蔚 山をつなぐ要所に位置する。慶州駅を中心として西側には在来市場 を含む駅前商店街、東側には鉄道官舎と日本人町が集中的に形成さ れ、多くの日本人が居住していた。駅前商店街は ‘T 字型” の主道 路によって構成され、東側の鉄道官舎地区は格子状の街区を形成し ている。慶州鉄道官舎は二戸一形式の平屋で、 5 等級、6 等級、7 等 級 A、7 等級 B、8等級の五つタイプに分けられ、建設時には全ての 出入口は北側に、庭は南側に設けられていた。

\section{1-2 調查概要}

本稿は 2 次にわたる現地調查を基にしている。第 1 次調査（2006 年 1 月 10 日一-15日）において予備調查を行い、居住者へのヒヤリン グを行うと共に、『慶州郡誌』、『慶州市誌』、地籍図、都市計画図な どの文献収集を行った。第 2 次調查 (2006 年 6 月 2 日-10日) では、 鉄道官舎地区の 23 軒の住居について実測調查を行った。また、居住 者の属性 (年龄、家族構成、出身地、職業、旧鉄道官舎への入居時期、 前居住者との関係) や住居の増改築に関するヒヤリング調査を行っ た。

\section{2. 慶州と鉄道町の立地}

\section{2-1 度州の概要}

慶州は、古代の新羅王国（4世紀半ば〜935 年）の首都・金城とし て政治的、社会的、経済的、宗教的、文化的中心地として発展して きた。新羅が高麗太祖に降伏した際 (935)、「慶州司」という官庁が 置かれ、この時「慶州」という名称が生まれている。11)

慶州地域には新羅時代の遺跡や古境が数多く散在している。慶州 は、1955 年 9 月に市に昇格し、1960 年代に入って文化財の保存と国 際観光文化都市ぶくりを目標として土地区画整理事業や、都市再開 発事業などを実施している。1970 年代に入ると、当時の大統領の指 示によって本格的な都市整備が行われ、道路・宿泊施設の建設と共 に文化遗産の復元整備 が行われた。こうした整 備の結果、慶州は韓国の 国民ならだれもが訪れ る観光都市としての基 盤を確立することにな った。

\section{2-2 慶灯鉄道町の立地}

慶州における最初の 鉄道駅は、1924 年釜山一 慶州間の鉄道敷設と共 に図 2 に示すように慶州 邑城の南側に建設され た。その後、1932 年に現 在の位置に移転され、慶 州駅と慶州邑城の間に 駅前商店街が形成され た。慶州駅の南東側に旧

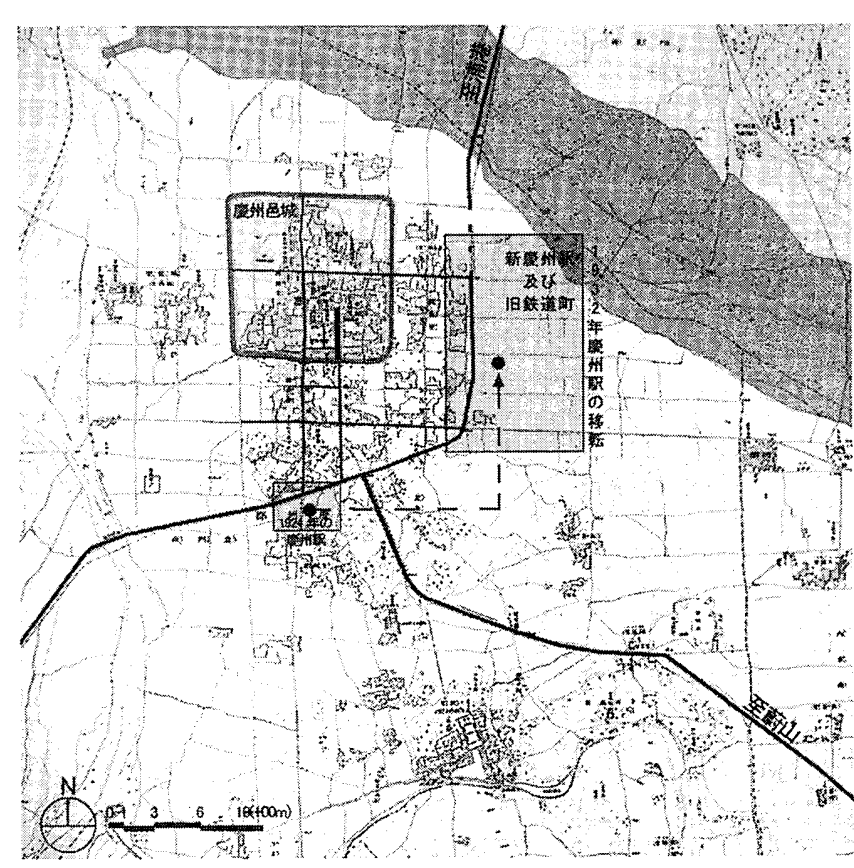

图 2 鉄道数設以前の鹿州市街地图
鉄道官舎建設され、東側に旧日本人町が形成されることになった。

調查対象である鉄道官舎は 1932 年〜 1935 年の間に 37 棟 74 戸が建 設され、駅員の居住空間としてその役割を果たしてきた。

鉄道官舎地区と駅前商店街は慶州駅と線路によって分断されてお り、街区構造も以下のように異なっている。慶州駅の西側には、駅 の建設以前から T字型の道路があり、それを軸として駅前商店街が 形成されている。慶州駅と慶州邑城の間の広い地域が慶州の中心市 街地として発展している。東側の旧鉄道官舎地区や旧日本人町は、 川の汇濫原を開拓した地域に新たに日本人居住地として建設された ことから、この地区には駅前商店街の街区に見られる昔ながらの路 地はほとんど見当たらない。

このような立地の差は、駅前商店街地区と慶州鉄道官舎地区の変 遷にも影響を与えている。駅前商店街地区は、慶州の中心市街地と して、商業、行政、金融の中心となっている。鉄道官舎地区は、長 い間国有地であり、払下げが終わった後も、道路を含む所々の土地 が鉄道局所有の土地となっており、また、開発の制限が厳しかった ため、現在も多くの平屋が分布している。

\section{3. 鉄道官舍地区の權成}

鉄道官舎地区は慶州駅の南東部の平坦な土地にあり、図 4 に示す ように東酉を走る旧線路であった貫通道路によって南北二つに分け られている。また、さらに南北の各地区は十字形の主道路によって 四つの街区に分かれている。

1931 年に慶州から大邱までの国鉄京釜線の分線の増設と共に、新 駅が建設され、1932 年から 1935 年までの 4 年間で 37 棟 74 戸の鉄道 官舎、そして二つの共同會庫が建てられた。

各街区にある旧鉄道官舎は 3 面以上が道路によって曲まれており、 南北の各四つの街区ごとに集会場、共同倉庫、地蔵堂が設けられて、 旧鉄道官舎に居住する駅員のコミュニティ施設として使われていた。 3-1 街区の構造と街路体系

慶州鉄道官舎地区は、東西約 $230 \mathrm{~m}$ 、南北約 $600 \mathrm{~m}$ の規模をしてお 
り、以上のように、鉄道線路に直交する主道路によって南北に分け られ、格子状の道路によって区画されている。

全体は、 $\mathrm{A}-\mathrm{H}$ の八つの街区で構成されている。B 街区には 6 等 級官舎、C 街区には 8 等級官舎、D 地区には 5 等級官舎と 6 等級官舎、 $\mathrm{F}$ 街区には 7 等級 $\mathrm{A}$ 官舎、 $\mathrm{G}$ 街区と $\mathrm{H}$ 街区には 7 等級 $\mathrm{B}$ 官舎が建設さ れた。そして $\mathrm{A}$ 街区と $\mathrm{E}$ 街区には、集会場、共同倉庫、地藏堂など が設けられていた。しかし、現在は、一部の倉庫だけを残しマンシ ヨン、戸建住宅、店舗などが建設され、住民の集会場の機能を失っ ている。

また、各道路は、官舎地区の居住者により貫通道路（東 一西)、主道路(交差点(1)、(2)、(3)を通る道路)、副道路 (その 他の格子状の道路) と呼ばれており、平均幅は各々 $15 \mathrm{~m} 、 8 \mathrm{~m} 、$ そして 5mである。

敷地は、約 $60 \mathrm{~cm}$ ほどの石垣で基礎を築き、生垣の塀で境 界を分けている。そして、敷地と道路の境界に溝を掘り生活 用水や雨水を流す下水路として用いていた。また、貫通道路 の雨側には通行時に官舎を直接見通すことが出来ないよう に平均幅 $5 \mathrm{~m}$ の緑地が設けられていた。現在、こうした日本 植民地期当時の街区構造と街路体系はほとんど変わらず残

\section{表 1 度州旧鉄道官舎の実測概要}

\begin{tabular}{|c|c|c|c|}
\hline & 建葚類型 & 住 所 地 & 建等年度 \\
\hline KA1 & 元倉值の㠰き地 & 费尚北道鹿州木皇吾洞 144-74番地 & 1970年 \\
\hline KA2 & 元合府の空き地 & 雨尚北道度州市皇吾洞144-68番地 & 1970年 \\
\hline KA3 & 共同合席管理堂 & 费消北道鹿州术皇苦洞 144-64番地 & 1932年 \\
\hline KB1 & 6等級官舍 & 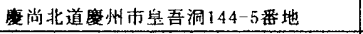 & 1933年 \\
\hline KB2 & 6等䑹官舍 & 尚北道韯州市皇吾洞141-10番地 & 1933作. \\
\hline KC1 & 8等級官舎 & 慶尚北道费州方皇五洞 144-16番地 & 1932年 \\
\hline $\mathrm{KC2}$ & 8等釉宣走 & 慶消北道度州市皇吾洞 144-23番地 & 19324: \\
\hline KC3 & 8等級官食 & 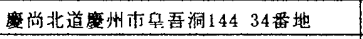 & 1932年: \\
\hline KC4 & 8等級宫昘 & 费尚北道屡州市皇吾洞144-32番地 & 1932年 \\
\hline KC5 & 贯通道路の絊地 & 尚北道鹿州市皇琴洞 144-38番地 & 1933年 \\
\hline KD1 & 5等級它舍 & 屡尚北道慶州市息吾洞 144-15番地 & 1933年 \\
\hline KD2 & 5篓級官含 & 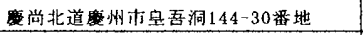 & 1932年 \\
\hline KE1 & 元会麻の空き地 & 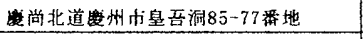 & 1970年. \\
\hline KE2 & 元合麻の公き地 & 度尚北道鹿州市皇去洞85-11番地 & 1970 年 \\
\hline KF1 & 7等䄲 $\Lambda$ 官舎 & 度尚北道慶州市皇吾洞85-8，85-59番地 & 1934許: \\
\hline KF2 & 7等耙A官含 & 宽尚北道慶州才丢吾洞85-17番地 & 1934年 \\
\hline KF3 & 7等級A官走 & 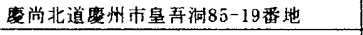 & 1934年 \\
\hline KF 4 & 7等級A官舎 & 事尚北道鹿州市皇叴洞85-24番地 & 1934年 \\
\hline KG1 & 7等級B它舍 & 患尚北道慶州市皇吾洞85-31番地 & 1935年 \\
\hline KG2 & 7等制B官舍 & 尚北道淃州市皇吾洞85-32番地 & 1935年. \\
\hline KG3 & 7 䈉級B宙含 & 费尚北道鹿州市皇告洞85 43番地 & 1935年 \\
\hline $\mathrm{KH} 1$ & 7等粐B'它舍 & 嗻尚北道庭州市息吾洞85-40番地 & 1935年 \\
\hline $\mathrm{KH} 2$ & 7等䄲B管含 & 砖消北道慶州市吾洞85-39番地 & 1935年 \\
\hline
\end{tabular}

\section{表 2 鹿州旧鉄道官舎の各等級別平面構成}

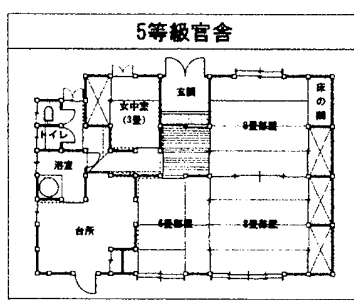

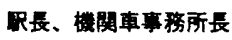

28. 5 坪

$468 \mathrm{~m}(26 \mathrm{~m} \times 18 \mathrm{~m})$

木造、土・モルタル㷱 セメント瓦

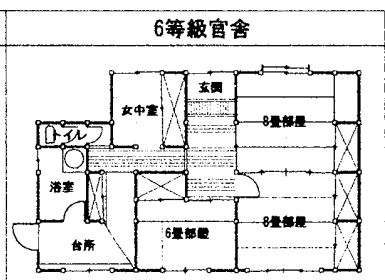

捕線重務所長、副㧽長

25. 8 坪

$468 \mathrm{~m}^{\prime}(26 \mathrm{~m} \times 18 \mathrm{~m})$
木造、土・モルタル壁 セメント瓦

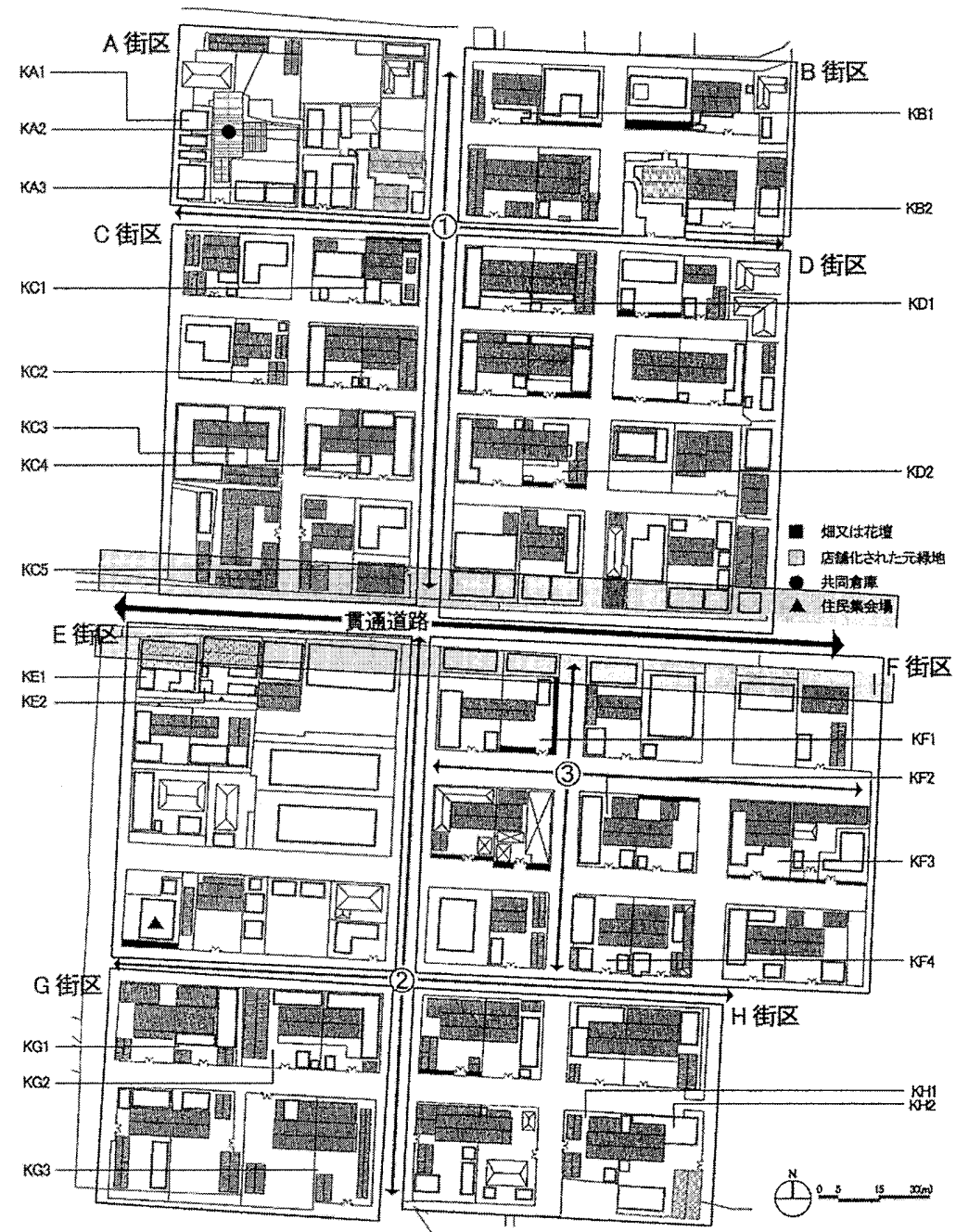

图 4 度州鉄道官舎の四羁
つている。1970 年代半ばから赛施された上下水道工事による道路の 抎張、貫通道路雨側の緑地の店舗への変化、生垣の塀がコンクリー トブロック塀に変化するなど部分的な変化以外、現在まで当時の様 子がそのまま残されている。

\section{3-2 鉄道官舎の類型と配罚}

鉄道員の居住空間として建設された鉄道官舎地区は、鉄道官舎、 共同倉庫、共同井戸、集会場、そして地藏堂などで構成されている。

官舎の平面構成は、表 1 に示寸ように 5 等級、6 等級、7 等級 A、 7 等級 B、8 等級官舎の五つのタイプからなっている。出入口や玄関 
は全て北側に位置し、庭は南側に置かれていた。しかし、寒い冬場 に北側からの厳しい風を遮断するため、敷地に面している畑などに 繫がる勝手口の利用のため、さらに、祭祀の時北からの出入は先祖 の霊が通る死者の通路と認識されているため、韓国では北側の出入 を避けるのが一般的である。この北入の平面構成は、払い下げ以後、 居住空間が大きく変わる要因となったと考えられる。

東西の貫通道路の北側に位置している ABCD 街区が 1932 年〜1933 の 2 年間で先に建設され、その後 1933 年〜1935 年の 2 年間で EFGH 街区が建設された。 $\mathrm{ABCD}$ 街区の配置は 5 等級官舎を中央に膡き、そ れを 6 等級官舎と 8 等級官舎が囲むアハターンをとっている。EFGH 地 区は北側に 7 等級 $A$ 、南側に 7 等級 $B$ が並ぶパターンである。A・E 地区は北西部に配置され、共同施設が設けられている。

主な共同施設として、飲料水としても使われていた三つの共同井 戸と、A街区と $\mathrm{E}$ 街区に共同倉庫、集会場、地蔵堂があった。しか し、1970 年代半ばに上水道が整備され、井戸は埋められた。また、 最近まで駅の會庫として使われていたA街区の倉庫一棟以外は撤去 され、その跡地にマンション、戸建住宅、養老院、店舗が建てられ ている。

\section{4. 轫道官舎の变容}

\section{4-1 旧鉄道官舍地区の居住者}

23 軒の内、1970 年の払下げ以前から住んでいる KF1 の居住者を除 いた 22 軒の居住者は慶州市の外部から 1980 年〜1985 年の間に旧鉄 道官舎を購入し移住している。以前の居住者は鉄道関連に勤める人 が多かったが、現居住者は、慶州郊外地域で農業をするのが KB2、KD1、 KD2、KF2、KF4、KG1、KG2、KG3、KH1、KH2 の 10 軒、そして、慶州郊 外の工場で働いているのが KA2、KB1、KC1、KC2、KC4、KF3 の 6 軒、 そして商業をするのが KC5、KE1、KE2、KF1 の 4 軒である。家族構成 は、老夫婦と棌が主に居住し、郊外地域に職場がある夫婦からなる 3 世代同居タイプが 23 世帯の内 18 軒で最も多い。また、高齢世帯主 の年齢は 60〜78 歳であり、主な生活費は別棟を増築した賃貸部屋の 家賃収入によっている。

\section{4-2 外部空間の変容}

外部空間に着目すると、図 4 に示す(1)、(2)、(3)の十字形道路を除 いた副道路の利用に大きな変化が現れている。その外部空間の変容 の特性として「텃밭(トッバッ)」 ${ }^{12)}$ の形成と副道路の「고샅(ゴサッ)」

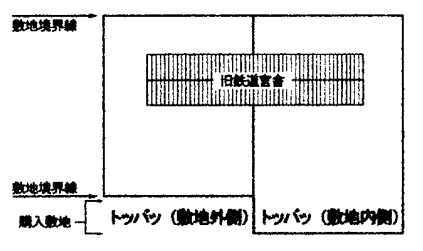

图 5 「トッパッ」の形成パターン
13) 化を指摘できる。

(1)「トッバッ」の形成

「トッバッ」は、敷地の中の 余った土地を利用する菜園や 花壇のことである。普通マダ ンの一部を利用して菜園が造 られる。対象地区では、1970 年代前半住宅と共に一部の道路の払下げが行われた後に「トッバッ」 が造られるようになった。

図4に示すように12 ヶ所でトッバッ」が造られており、そのほと んどは南側に副道路と接する敷地に集中している。拡張された敷地 利用の一つのパターンと考えられる「トッバッ」は、副道路の平均幅 が 6〜 $7 \mathrm{~m}$ で他の地区より広い B 地区、D 地区と F 地区に最も多く分 布し、町を歩く人との触れ合う機会を增やす空間となっている。
(2)副道路の「ゴサッ」化

「ゴサッ」は、幅広い道路から 敷地に入る前のマダン化した路 地をいう。私有地である宅地内に 入る前に形成される最も共同性 の強い外部空間である。韓国伝統 村の場合では通常 3〜5 棟每に 1 〜2の「ゴサッ」が形成されており、 1〜2 個の井戸と洗濯場が設けら れている。

慶州旧鉄道官舎の場合は棟の 数とは関係なく道路幅の狭い副 道路を中心としてけゴサッ」が形 成されており、副道路の幅が広い

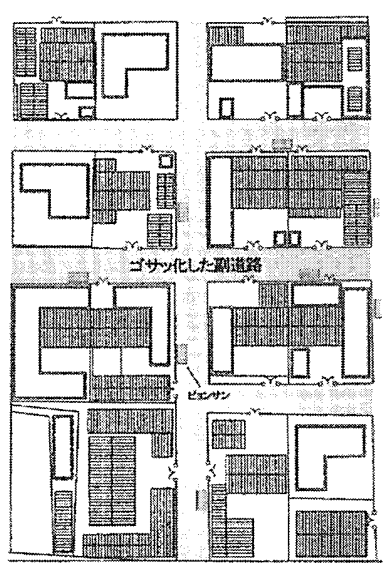

图 6 副道路の「ゴサッ」化 南側の $F$ 地区、 $G$ 地区、H 地区より、B 地区、 $C$ 地区、 $D$ 地区の副道路 の「ゴサッ」化が目立つ。特に、C 地区にある格子状の副道路は車の通 行がない「ドンネマダン」14) 化した「ゴサッ」に発達している。その「ゴ サッ」には、평상(ピョンサン・平床 $)^{15)}$ が置いている場合が多くあり 普段は年寄りの談話場となって、時には下校した子供たちの遊び場 にもなる。「ゴサッ」は、地区のコミュニティ空間として重要な役割 を果たしている。

\section{4-3 出入口の位置变更と内部空間の变容}

1970 年代前半に行われた払下げ以後、74 軒の内 (2)、(3)、(10)、 (15)、(17)、(36)、(44)、(45)、(53)の 9 軒は二戸一の片方を撤去 し新築しており、鉄道官舎の要素が残っていない。出入口の位圈の 変更パターンに着目してみると、この 9 軒と北側の出入口を維持し ている(39)、(40)の 2 軒を除き、東側一の出入口の変更 5 軒、西側 への変更 5 軒、そして南側への変更 53 軒など全 63 軒で出入口の位 㯰の変更が行われている。

出入口の位固の変化により居住空間の構成は大きく変化している。 その中で最も目立つのは、庭が多用途の外部空間であるマダンへと 転用されることである。北出入口の位置が変化することにより庭と して使われていた空間がマダンへと転用され、それにより居住空間 の動線に大きな変化が起き、その結果内部空間の構成や機能変更に も影響を与えている。マダンが形成されることによって各官舎主屋 の南中央部にリビングが設けられ、大門、マダン、リビング、各室 という流れが主動線となる。台所は、主屋の北側へ位膡が変更され る場合が多い。便所は室内から室外一一旦移動し、上下水道が整備 された後再び室内に設けられている。以上のように出入口の位置の 変更は空閒構成を変える大きな要因である。また、出入口の位膡の 変化は敷地内部の空間だけではなく外部空間の要素である「ゴサッ」 が現れる要因となったと考えられる。北側にあった出入口は勝手口、 あるい忙賃貸棟の出入口として使われ、前方と背後にある住宅との 連絡が容易となる。

建物の増改築に着目すると、図 4 に示すように貸貸棟の増築がほ とんどである。また、貫通道路両側の元緑地に店舗を新筑する例が 多くみられ、小型商店街が形成されている。そして、集会場、共同 倉庫、地蔵堂などが置かれていた A・E 地区には、マンション、戸建 住宅、養老院、店舗が建てられ、コミュニティの場としての役割が ほとんど失われている。 
二戸一形式である旧鉄道官舎は一方だけの撤去は非常に難しく、 主屋は内部改造、あるいは、機能の追加など一部增築の改造行為に 止まっている。

図 7 に示すように、ほとんどの住居でマダンとリビングが接し、 主動線の役割を分担した上で各室に連絡しているのが分かる。増箱 された部分との位置関係は、表 3 に示すように、主屋においてはリ ビング、台所、部屋、トイレなど南北両側への室内空間の搪張が目
立っている。別棟の場合は東・西・南・北どの方向でも同じように 増築がなされている。別棟は貸貸部屋とされるのが最も多く、他に 事務室、店舗、室外トイレ、倉庫、浴室のような付属室として用い られている。特に、「ゴサッ」が発達している C 地区と F 地区の場合 は、賃貸部屋、店舗、事務室に使われている別棟は道路側に出入口 を設けており、「ゴサッ」を共同のマダンとして認識していると考え られる。

表 3 增改築の現状

\begin{tabular}{|c|c|c|c|c|c|c|c|c|c|c|c|c|}
\hline & 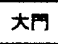 & リビング & 台所の移助 & $\frac{F 1 \mathrm{~L}}{\mathrm{~F}}$ & 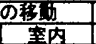 & 本坊 & $\frac{1}{2 x^{2}}$ & 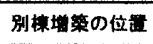 & 元出入口の用途 & マダンor庭 & 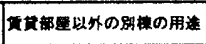 & 母居の主な空間変動 \\
\hline Ba1 & 霄 & & 中黒 & 需 & 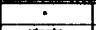 & 3 & $\cdot$ & $\div$ & $\div$ & $\div$ & $\cdot$ & 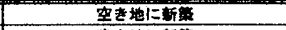 \\
\hline$\frac{10}{12}$ & 酋 & 商 & 西 & 中薄 & 重罴 & 3 & $\cdot$ & $\cdot$ & $\dot{\square}$ & $M$ & - & 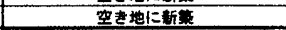 \\
\hline Kh & 事 & 中央 & 菄 & 票南 & 重北 & 3 & 8 & 西・雨 & $\cdot$ & $M$ & F使、濯 & 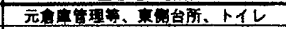 \\
\hline KBi & 咅 & 南中央 & 重南 & 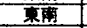 & 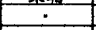 & 4 & 5 & 萳·北・西 & 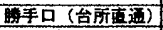 & & & 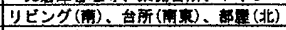 \\
\hline $\mathrm{X} 2$ & 董 & 市中央 & 酋执 & 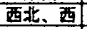 & $\cdot$ & 3 & 4 & 西・北 & 棰乎口 & $\mathrm{N}$ & FイL、浩害，再 & リビンク (亩)、台序 (西) \\
\hline KGI & 薑 & 率 & 申非 & $-\quad$ & 覀北 & 3 & 3 & 菓・通，北 & - & 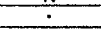 & & リヒンクグ(高)、トイレ・台质(扎) \\
\hline KC2 & 南 & 南 & 東 & 西高 & 整北，酉北 & 4 & 2 & 裹・北 & $\cdot$ & $M$ & トイレ、海室 & 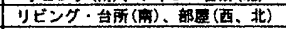 \\
\hline $\mathrm{KC3}$ & 董 & 需中央 & 中壮 & $\dot{\square}$ & 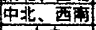 & 3 & 7 & 荲・南·非 & 帮手口 & $\div$ & & 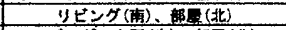 \\
\hline $\mathrm{KCA}$ & 需 & 需中央 & 䙵 & $\cdot$ & 中央 & 3 & $i$ & 真·南·北 & 腾乎云 & $\bar{M}$ & 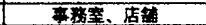 & リビング・台所 (南)、部量(北) \\
\hline KC5 & 蕫 & 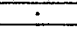 & 西南 & 重非 & $\dot{0}$ & 2 & $\dot{\square}$ & $\because$ & & & & 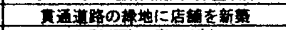 \\
\hline kno & 罱 & $\cdot$ & $\bar{\pi}$ & 西苚 & $\div$ & $\frac{5}{3}$ & $\div$ & 西 & 粍口 & $M$ & 㢆 & 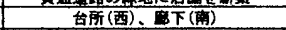 \\
\hline 102 & 賈 & 需中央 & 中北 & 䀰 & 中非 & 3 & 2 & 重 & 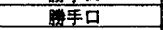 & $M$ & 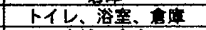 & 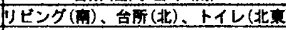 \\
\hline KE & 罱 & 雨中央 & 中批 & 中南 & 中地 & 2 & 4 & 蔓・要・南 & $T$ & $M$ & 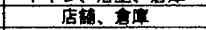 & 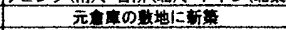 \\
\hline KE2 & 輋 & & 西 & 董南 & 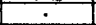 & $t$ & 2 & 南 & $\cdot$ & $M$ & 店转 & 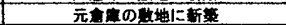 \\
\hline KE1 & 蓄 & 南中央 & 中非 & 菓 & $\div$ & 4 & . & 等 & 平口 & $\bar{M}$ & 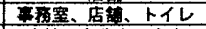 & 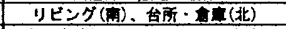 \\
\hline KF-2 & 满 & 耑中央 & 重北 & 菄 & 中抽 & 3 & 3 & 䠓·批 & & $M$ & 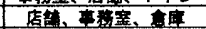 & 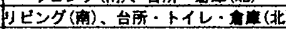 \\
\hline KF 3 & 䍣 & 需 & 西 & 中北 & 中央 & 3 & 3 & 㶾・批 & 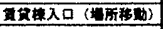 & $\mathrm{M}$ & 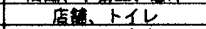 & 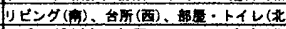 \\
\hline 慗4 & 罱 & 䨍帕央 & 茜 & 㶾速 & 虫菲 & 4 & 5 & 望・西蔽 & 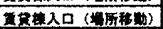 & $\bar{M}$ & トイ , A & 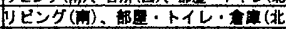 \\
\hline KGI & 萳 & 等蛙 & 荲 & 苯拕 & 榃菏 & 3 & 5 & 童 & 㬴羊口 & $\bar{M}$ & I & 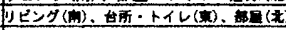 \\
\hline KEP & 薄 & 策安台 & 西 & . & 中央 & 5 & 4 & 㶾 & 1 & $M$ & 基 & 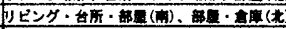 \\
\hline KG3 & 南 & 雬 & 西南 & 䠓雩 & . & 4 & 5 & 菄 & . & $\mathrm{M}$ & 店 & 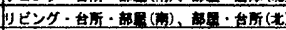 \\
\hline KMiI & 䠓 & $\because$ & 中南 & 重 & $\cdot$ & 3 & 8 & 䠓. 真 & 腈手口 & $M$ & 量㫫 & 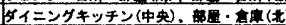 \\
\hline KH? & 宩 & - & 中萳 & 莤 & - & 3 & 7 & 宩. 葫 & 整手口 & $M / N$ & 夏粗 & 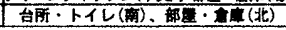 \\
\hline & & & & & & & & & & & & 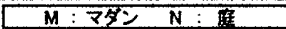 \\
\hline
\end{tabular}

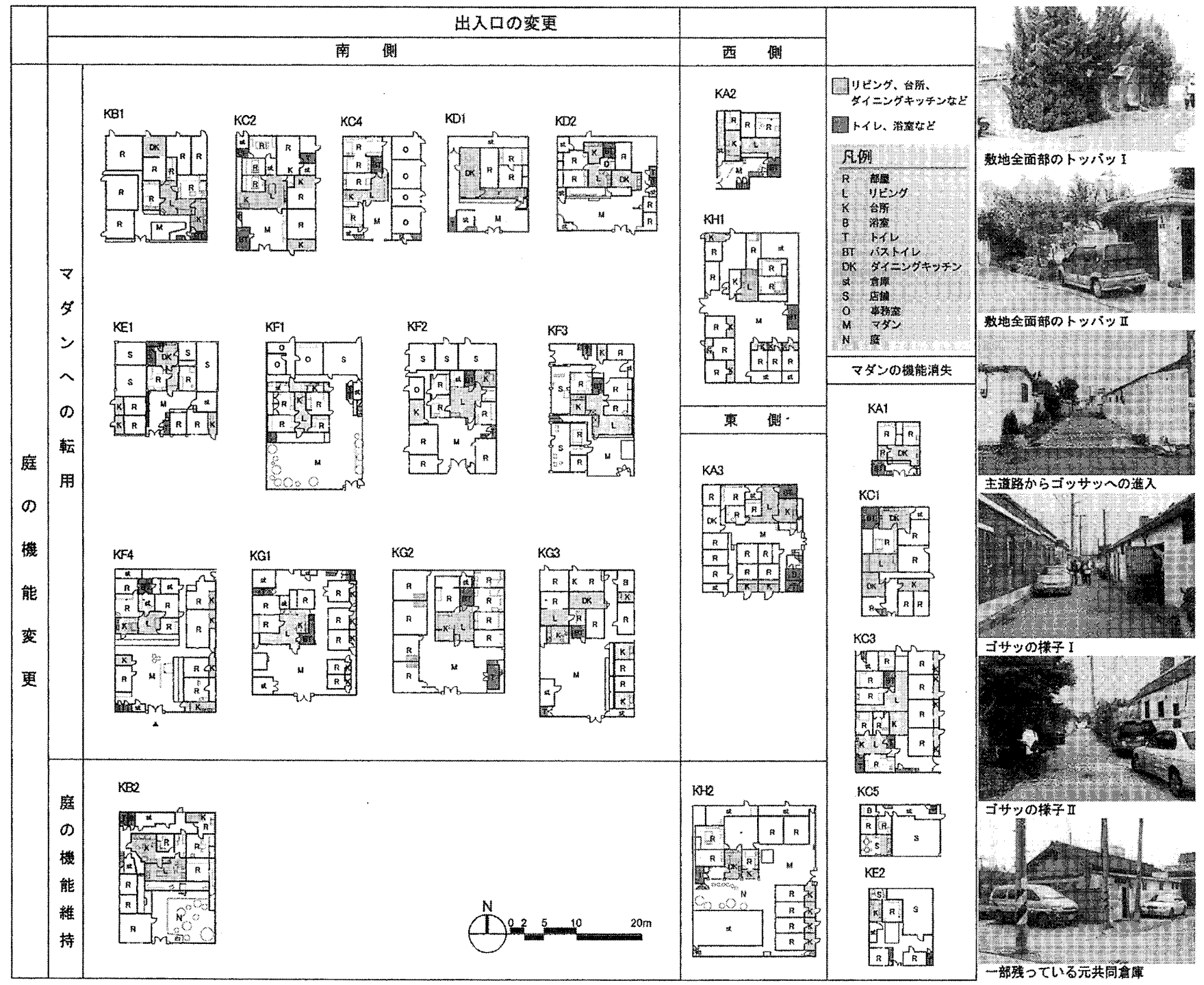

図 7 居住空間変容のパターンによる類型 
4-4 マダン・リビングの出現

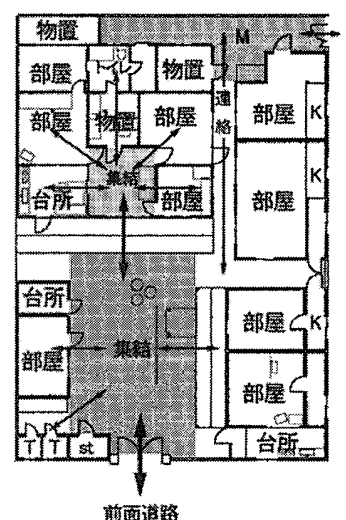

図 8 マダンとリビングによる

動線構造
「トッバッ」、「ゴサッ」は敷地 内と外の関係に関わる変化であ る。居住空間の変容について、最 も注目すべきことは、庭が転用さ れたマダン ${ }^{16)}$ と台所・廊下を改 造したリビングの出現である。マ ダンとリビングの出現も、出入口 の変更に大きく関係している。マ ダンは前面道路から敷地内、そし て室内に入る動線をコントロー ルする韓国の住居においては最 も重要な空間要素である。

実測調査をした 23 軒の内、西 側に出入口を変更したKA2、KC3、

KH1、東側に出入口を変更した KA3、KH2 以外の 18 軒が南側に出入口 を変更している。

KB2 と KH2 の 2 軒は、出入口の変更と共に庭がマダンへと変更され、 その後再びマダンが庭と変更された例である。また、KA1、KC1、KC3、 KC5、KE2 の 5 軒は、大規模な増築によりマダンの機能が消失し、外 部通路がマダンの位置に残っているだけである。以上の 7 軒を除い た 16 軒で庭がマダンに転用され、マダン本来の機能を維持している。

マダンの種類をみると、元庭があった南側のマダンは、「アンマダ ン」7、主屋の背部にあるマダンは「ディッマダン」 ${ }^{18)}$ 、東・西の道路 側にあるマダンは「ヨップマダン119) と呼ばれて区別されている。KD2、 KF3、KF4、KG1、KH1、KH2 の「ディッマダン」は台所関係の作業や乾燥 野菜などを置く空間として使われている。台所、又は、台所付属倉 庫と接している場合が多い。また、KB2、KD1 の「ヨップマダン」は、 主に「ジャンドック」さ20) を置く空間としてよく使われ、水道の蛇口を 設けているのが特徴である。

リビングのほとんどは台所と廊下を改造・増策したもので、住居 の中央部南側に設けられている場合が多い。来客の接待や家族の団 臬空間として使われている。春から秋にかけての暖かい時期には、 家族が集まるのはほとんどこのリビングに集中するほど住居の中心 空間となっている。

図 8 に示すように、マダンから始まる動線はリビング、及び、別 棟の各室へ直接つながる。また、リビングから始まる主屋の動線は 直接各室につながっている。

ソファーなどの椅子式の家具が置いている場合もあるが、大半は 床座式生活を基本としている。特に、夏の暑い時に家族が食事する 場合は、風通しがいいリビングを使うところが多い。また、KA2、KA3、 $\mathrm{KB} 2 、 \mathrm{KC1} 、 \mathrm{KC2}$ 、KF2、KG1、KG2 では、隣接した部屋との間に引きき を設置し、リビングと慗いだ広い空間で法事などの祭祀を行ってい る。以上のようにマダンとリビングは、動線の終結・分散の起点で あり、多用途に用いられる居住空間の中心である。

\section{4-5 增改策のプロセスとその特徽}

前述のように、旧鉄道官舎は、二戸一形式で二つの住宅が構造体 を共有しているため主屋の全体的な改造は非常に困難である。一般 に増改筑による居住空間の変容過程は図 9 のように示される。

主屋では、トイレと台所の位置が変えられる例が多い。畳はほと
んど床暖房（オ

ンドル）に変え

られている。ま

た、床暖房のた

めにボイラ一室

が追加されてい

る。表 2 に示す

ように敷地面積

や建蔽率の小さ

い下級官舎に行

くほど追加され

た部屋の数が多

くなっているの

が分かる。実測

した 23 戸の内、

KH1 のように最

大 8 つ部屋が

造られているも

のがある。

また、ほとん どの住居で、面 積の広狭には関 わらず、主屋の 南側、リビング と接している部 屋をクンバン ${ }^{211}$
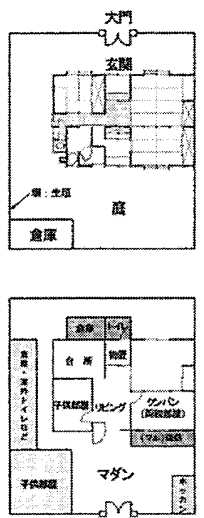

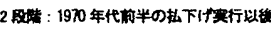

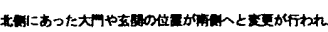

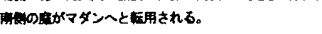

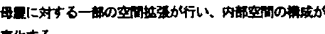
化可万。

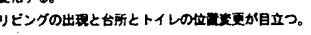

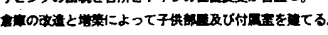
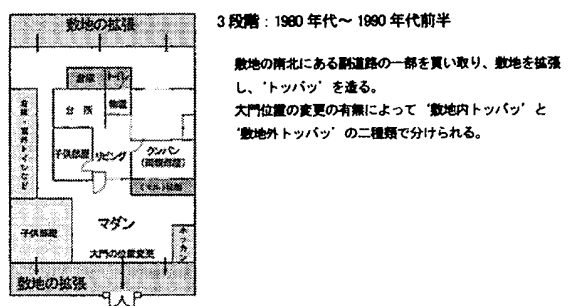

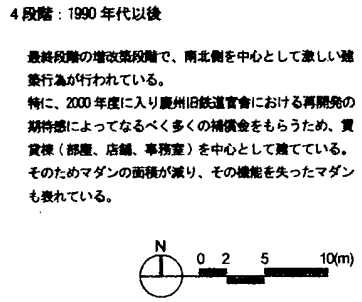

图 9 堌改築のプロセス

と呼ぶ両親部屋に改造しているのが確認でき、生活様式によって部 屋の機能や意味が付与され、それに伴う形態の変化も起きていると 考えられる。こうした増改築は、図 9 に示すように鉄道官舎の払下 $け ゙ \rightarrow$ 主屋の一部の増改築と別棟の増築 $\rightarrow$ 副道路の一部購入による敷 地の挔張 (トッバッとして使用) $\rightarrow$ 拡張した敷地に別棟を増築する (別棟のほとんどが賃貸用となり、マダンの面積が減少・機能消失） といら大きく 4 段階に分けられる。

住民へのヒヤリング調查によると“押入などの収納空間が多い。 奥を取り外すと部屋が広く使えるため生活しやすい。空が多いため 冬は寒いが、夏は換気性がよくて涼しくて湿気も溜まらない。とい う前稿で論じた三浪津旧鉄道官舎でのヒヤリング調査と似たような 応答と共に、“教地とあまり変わらないレベルにある平坦な副道路は 比較的に安全であるため子供達の遊び場として相応しい。町の人々 と触れ合ういい場所となっている。のような街区状況と利用実態に 関する応答も多くある。このような結果から見ると、最初の段階か ら、車道・人道を分けるために、車通行の主道路と生活と密着した 歩道である副道路に分けて設置した街区計画、換気と湿気を綿密に 考虑した設計・計画、また、部屋の転用性、融通性は、一定程度評 価されていると考えることができる。

\section{5. まとめ}

建設から約 70 年余りが経っているのであるが、現在も旧鉄道官舎 地区はかつての姿をよくとどめている。格子状の幅広い街路網、建 物の配置手法など、韓国にはない特徴を保っている。本稿では現地 
調査を基に居住空間の変容の実態を明らかにした。その主要な点は 以下のようである。

(1) 居住空間の変容は、1970 年代前半に行われた払下げ以後に本格 的に始まっている。

(2) 外部空間の変容として興味深いのが、「トッバッ」と「ゴサッ」の 出現である。いずれも、地区内のコミュニティ空間として重要な 役割を果たしている。街路計画として、車道・人道を分けていた こと、また道路幅に一定の余裕を設けていたことが、「トッバッ」 と「ゴサッ」という空間の出現を促したと考えられる。

(3) 1980 年代前半までの居住者は鉄道関係職員であり、1980 年代半 ばからは、以前の居住者から住宅を購入し、慶州郊外地域から慶 州市内に移住した居住者が増えている。家族構成は、両親と夫婦・ 子からなる 3 世代同居タイプが 23 世帯の内 18 軒で最も多い。夫 婦は主として郊外地域に職場をもっている

(4) 住居の変容としては、出入口の位置の変更、庭のマダンへの転 用、主屋の増改築、別棟の増築などが見られる。

(5) 主屋については、主屋の南端に隌下と台所が改造されたリビン グが現れ、台所とトイレの北・西方向へと位置を変更し、付属室 を增筑するなどの空間の変化が多く見られる。項の結果、家族の 共同生活や法事など、ほとんどの家庭内の行動が新たに現れて来 たリビングで行う中心空間となっている。郎下を改造、増筑した リビングは住居の中心空閒として使われている。また、主屋の南 側にあった台所は、日当たりが良くない所に位膡を変えられてい る。トイレは、室内一室外一室内という位置の変更が行われる。 室外に残っているトイレは貸貸部屋用のトイレとして使われてい る。増築あるいは付加については、居間の場合は南方向に、付属 室の場合は北方向に拡張される場合が多い。

（6) 1990 年代以後、別棟として、大規模の賃貸部屋の増築が行われ、 マダンの機能を失った住居が数多くある。元出入口であった北側 の門は勝手口、あるいは、賃貸棟の出入口として使われている。

(7) 増改築のプロセスは、鉄道官舎の建設 $\rightarrow$ 主屋の一部の増改筑と 別棟の增築 $\rightarrow$ 副道路の一部購入による敷地の抗張(トッバッとし て使用) $\rightarrow$ 拡張した敷地に別棟を増筑するという大きく4段階に分 けられる。

(8) 襖、押入、天井の高い構造体は、そのまま残されている。襖に よって空間をつなげることも行われているし、押入れも物入れと して使われている。

日本人によって韓半島の各地で建設された鉄道官舎は、日式住宅 のひとつの形式として移入され、韓国人によって居住されてきた。 住居の要素として、以上のように、そのまま使われ続けるものと変 更が加えられたものがある。本稿では、居住空間の変容を具体的に 明らかにした。土地所有関係の分析は続稿としたい。また、慶州旧 鉄道官舎地区とは異なる街区の特徴を持っている慶尚北道安東の旧 鉄道官舎地区の考察を別稿としたい。

\section{参考文裁}

1)八ウジング・スタディ・グループ『韓国・現代・居住学』，建築知識, 1990 年 2) 朝鮮総督府鉄道局『朝鮮鉄道線路案内』朝鮮総督府鉄道局出版部、明治 44 3) 慶州誌編篗委員会『慶州誌』慶州文化院

4）金载植、金基汶『慶州風物地理誌』普宇文化剘団 1991.8

5) 朝鮮建築会『朝鮮之建勧』第 1 20 巻 朝鮮建築会 1918 年一1941 年
6)孫禎睦『日本統治下朝鮮都市計画史研究』柏書房 2004 年 12 月

7) 孫 禎睦『韓国都市变化過程研究』耕文社 2000 年 6 月

8)이현회 Lee Hyeun hea (李賢姬)「韓国에 있는 日式住居의 変遷과 그 影響에 관한 研究」漢陽大博士学位論文、1993 年

9)朴 重信「日本植民地期における日本人移住漁村の形成とその変容に関す る研究小、京都大学博士踰文、2005 年 3 月

10) 채기병 Chae Gi-Byung, 김태영 Kim Tai-Young、「鉄道建設에 따른 近代的 都市構造의 形成에 관한 研究」大韓建築学会学術発表論文集第 17 卷 2 号 pp607-614、1997. 10

11) 주우일 Ju U-IL、김상호 Kim Sang-Ho、이상정 Lee Sang-Jung「近代化 過程 에 建立된 晋州 鉄道官舎의 平面類型에 관한 研究」大韓建築学会計画系 論文集 第 14 巻 8 号 pp155-162、1998. 8

12) 김수영 Kim Su-Young、박용환 Park Young-Hwan「해방이전 철도관사의 평면톡성에 관한 연구」大韓建筑学会学術発表論文集第 20 巻 1 号 pp313-316、2000. 4

13)안성호Ahn Sung-Ho「일제강점기 관사의 주거적 의미에 관한 연구」 大韓建築学会計画系馀文集 第 17 巻 11 号、2001. 11

14) 우동주 Woo Dong-JU「日帝時代 聯立型官舎의 空間変容에 관한 現場研究」 大韓建築学会計画系論文集 第 7 巻 6 号、 1991.12

注

注 1）日本植民地期における韓国の日本人によって形成された鉄道町の形成と 変容に関する研究は「鉄道町の形成と韓国における近代都市化」、「日本住文 化と韓国住文化」の二つを基軸にした文化変容の研究である。本研究の対象 は比較的に開発が少ない中小都市である三浪津邑、慶州市、安洞市、倭館、 釜山市九浦など、鉄道駅周辺の町、鉄道官舎の現地調查によって分析を行っ ている。

注 2）外国人専用居住地域である居留地が設置された港湾地域で、治外法権的 な居住地である。韓国では江華島条約の締結を起点として、1877 年の釜山開 港以が日本の居留地建設の突破口となった。

注 3）趙聖民、布野修司、韓三建「日本植民統治期における韓国密陽・三浪津 邑の都市形成と土地所有変化に関する研究」日本建築学会計画系論文集第 607 号 p 79-86 2006年 9 月 趙聖民、朴重信、金泰永、布野修司「韓国密陽・三浪津における旧日本人居 住地の形成と旧鉄道官舎の変容に関する考察」日本建築学会計画系論文集

注 4) 文献 2

注 5) 文献 5

注6) 文献 8

注 7) 文献 10

注 8) 文献 11

注 9）文献 12

注 10） B. C57〜A. D935 の新羅時代の首都であった。2000 年 12 月世界文化遺産 として登録された。

注 11) 文献 4

注 12）住宅敷地の内部、又は、接している外部にある菜園のこと。

注 13）広い道から住宅に接近する路地の一種で端部が広くなっている場所で ある。一般的に 3〜5 棟ことに1〜2 個があり、井戸と洗濯場が設けられてい る場合が多い。3〜 棟の居住者の共同空間であり家前にある子供の遊びにも 使われている。

注 14）町の集会場付近にある広場のような空間。町の共同作業や祭などの準 備が行われる各町にとっては中心となる場所で、祭堂などの聖なる施設が共 に配䍛されている場合もある。

注 15）住宅のマダン、又は、人が多く集まる場所に置かれている木製の誛台の 一種で、特に夏場の休㝆、食事、談話などが行われる重要なコミュニティの ための家具、ストリートファニチャーである。

注 16）韓国の伝統的民家では、動線の溜まり場、作業場、葬式、祝賀会など の儀礼に使われる多目的な外部空間である。特に、外部道路から始まる進入 動線を各室に分散させる動線をコントロールする機能を持つ空間である。

注 17）本来は、建物で囲まれている女性の居住空間にあるマダンである。し かし、現在は主屋の前面にある最も大きいマダンを通称している。

注 18）主屋の裹側にある小さいマダンのこと。食材を保管するなど台所と接 した所が多く、台所の付属空間と利用さる場合が多い。

注 19）主屋の側面にある小さいマダンで小物を直いたり、キムチなどの作業 漬ける子作業をする細長い空間。

注 20) 味噌、キム千などを清ける容器(ジャンドク)のこと。普通は、日陰があ るところに設けるが、慶州鉄道官舎の場合は敷地面積の制限により別棟の屋 上に設けることも見られる。

注 21）夫婦部屋のことで面樌や位置とは関わらないが普段南側のリビングと 台所と隣接している。両親と同居している場合は両親部屋がアンバンとなる。 